\title{
Woven Light Emitting Display
}

\author{
Inese Parkova, Riga Technical University, Institute of Textile Materials Technologies and Design
}

\begin{abstract}
Electrotextiles represent a huge potential in creating a new generation of flexible textile platforms for electronic systems and smart garments. In this research of electrotextile fabrication weaving method was used. Fully or partly replacing traditional (non-conductive) textile yarns with conductive textile yarns, it is possible to get woven conductive textile material or fabric circuit. In the paper weaving method is considered for electro textile design and process of flexible textile light-emitting display fabrication is described. Fabric with interwoven conductive yarns to which light-emitting diodes (LEDs) were attached was designed. This technology is not only limited to light illuminated displays but can also be used to build other smart textile constructions like sensors, conductive textile traces etc.
\end{abstract}

Keywords: smart textile, light emitting display, photonic textile, weave, conductive yarns.

\section{INTRODUCTION}

Clothing is an important and special part of our environment, as it is personal, comfortable, close to the body and used almost anywhere and anytime. Nowadays clothing has more functions than just climatic protection and good look. Developing smart and interactive apparel sector, clothing obtained additional ability to communicate with environment and its wearer [1]. The concept of communicative apparel may be perceived as the result of a convergence of two industries: textiles and electronics [2]. Communication can be achieved between clothing and the person who wears it or between clothing and the external environment and others. Such kind of clothing refers to any clothing or textile accessory that receives or emits information out of the structure that it is composed of [3]. Electrotextiles represent a huge potential in creating a new generation of flexible textile platforms for electronic systems and smart garments [4]. Smart textile systems have a different range of applications like medical (monitoring of health, medical therapeutics), safety (work wear and protective clothing), leisure and fashion etc.

In this study research is focused on photonic textiles development of flexible textile-based display what is compatible with clothing for casual or professional use. Flexible light emitting textile can be used as output interface integrated into communication clothing by representing different animated images directly on clothing. Different textile flexible displays can be designed for smart clothing applications, like - LED display, optical fibre display, OLED display etc. [3]. In this case LED display was fabricated since light-emitting diodes are low in cost, small in size and available in different colours. This makes it possible for such electronic components to be used to make textile-based flexible displays with ability to display static on animated pictures or text [3].

For electrotextile fabrication weaving method was used. Weaving involves two distinct types of yarns, called warp and weft, which are interlaced at right angles to form a fabric [5]. Fully or partly replacing traditional (non-conductive) textile yarns with conductive textile yarns, it is possible to get woven conductive textile material or fabric circuit.

\section{MATERIALS AND METHODS}

For electrotextile design digital hand looms were used with warp density 38 yarns $/ \mathrm{cm}$. Weave was projected in Weavepoint software. In warp and weft yarn systems cotton yarns were used, in some parts of textile for electrical connections copper yarns were used $(330 / 34 \times 7$ dtex/f). To woven samples light emitting diodes (LEDs) were attached. Electrotextile during weaving process is shown in Fig.1. - in warp system 4 conductive yarns are placed.

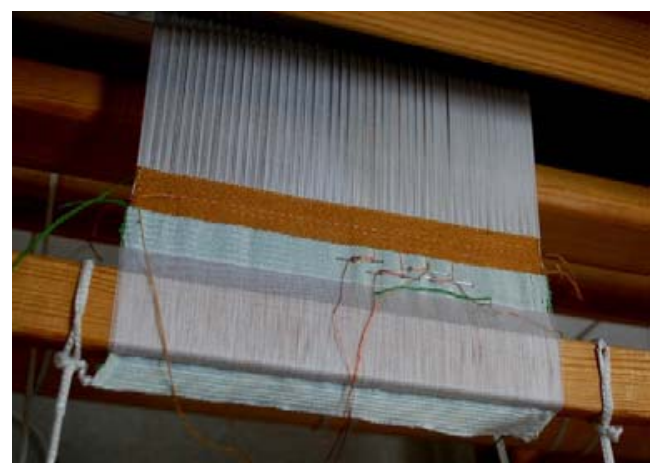

Fig.1. Electrotextile in looms during weaving process

\section{DESIGN OF LED DISPLAY SUBSTRATE}

For display textile circuit matrix construction was used (Fig.2), therefore it is necessary to place conductive yarns both in weft (assumed as anode) and warp (assumed as cathode) yarn systems. To avoid interconnection of both polarities in point of yarns intersection, electrotextile was designed as two layer fabric.

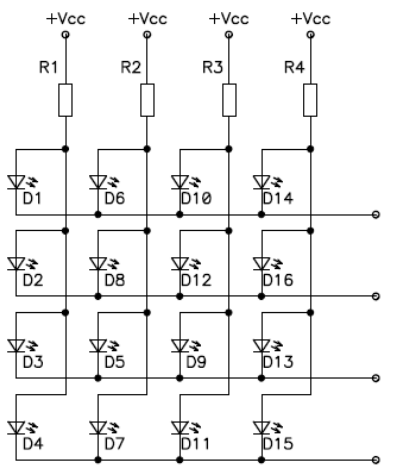

Fig.2. Circuit of LED display 
Projecting two-layer electrotextile for LED display substrate when both layers are interwoven, it was important to note proper:

- Type of weave;

- Placement of conductive weft and warp yarns;

- Interweaving point of top and bottom layer

For electrotextile double side satin 16/6 weave was used (weft faced satin 16/6 weave for upper layer of fabric and warp faced satin 16/6 weave for lower layer of fabric). Such kind of weave ensures sufficient contact area of weft floats for conductive traces, in its turn since the most part of warp yarns are located between both layers of fabric, additional insulation is provided between conductive weft and warp yarn contacts.

In order to lift conductive warp yarns on the left side of fabric, in each raport every first yarn of warp system in lower layer was interlaced just with one lower layer weft. To avoid connection of conductive yarns of upper and lower systems in its interweaving point, it was necessary to choose the proper weft row where conductive yarn could be woven. The fourth row was chosen where warp float of upper layer locates far enough from interweaving point of lower layer conductive warp yarn with lower layer weft float. Weave design in Weavepoint software is shown in Fig.3.

\section{LEDS PREPARATION AND ATTACHING TO ELECTROTEXTILE}

Light emitting diodes are available in different size range, housing type and architecture. Often used are diodes in tubular housing (T1) with diameter 3, 4 or $5 \mathrm{~mm}$ - using such kind of LEDs for e-textile design, diode's leads are rolled in loops (as it is shown in Fig.4.a.) what can be used for sewing LED to textile circuit with conductive yarns. It is handy to attach diodes in such way but due to quite high LED's housing diodes make very irregular surface on textile.

Light emitting diodes are available in flatter housing as well, for example - diodes in square housing with four leads (two leads for each polarity). Together soldered leads form loop what can be used for LED sewing on textile as it is shown in Fig.4.c. Surface mounted light emitting diodes (SMD LEDs) are smaller in size, for example - parameters of 0402 size SMD LED are $1 \times 0.5 \times 0.5 \mathrm{~mm}$. In this case there is a problem with the connection of electronic element and textile material because diode doesn't have leads. In order to attach SMD LED to textile material, to diode's soldering terminals metal accessories can be soldered what traditionally are used for jewellery or embroidery. Prepared SMD LEDs for sewing are shown in Fig.4.b.

Display substrates were woven with two ways of attaching LEDs:

- LED anode and cathode contacts are attached to electrotextile substrate after weaving;

- One polarity contact is attached to textile during weave, another polarity contact is attached to textile after it is woven.

The placement of conductive yarns in textile is shown in Fig.5.

Sample where LED anode and cathode contacts were attached to electrotextile after weaving is shown in Fig.x. Different size and form accessories (rings and beads) were proved (Fig.4.b.). however it is more suitable to use
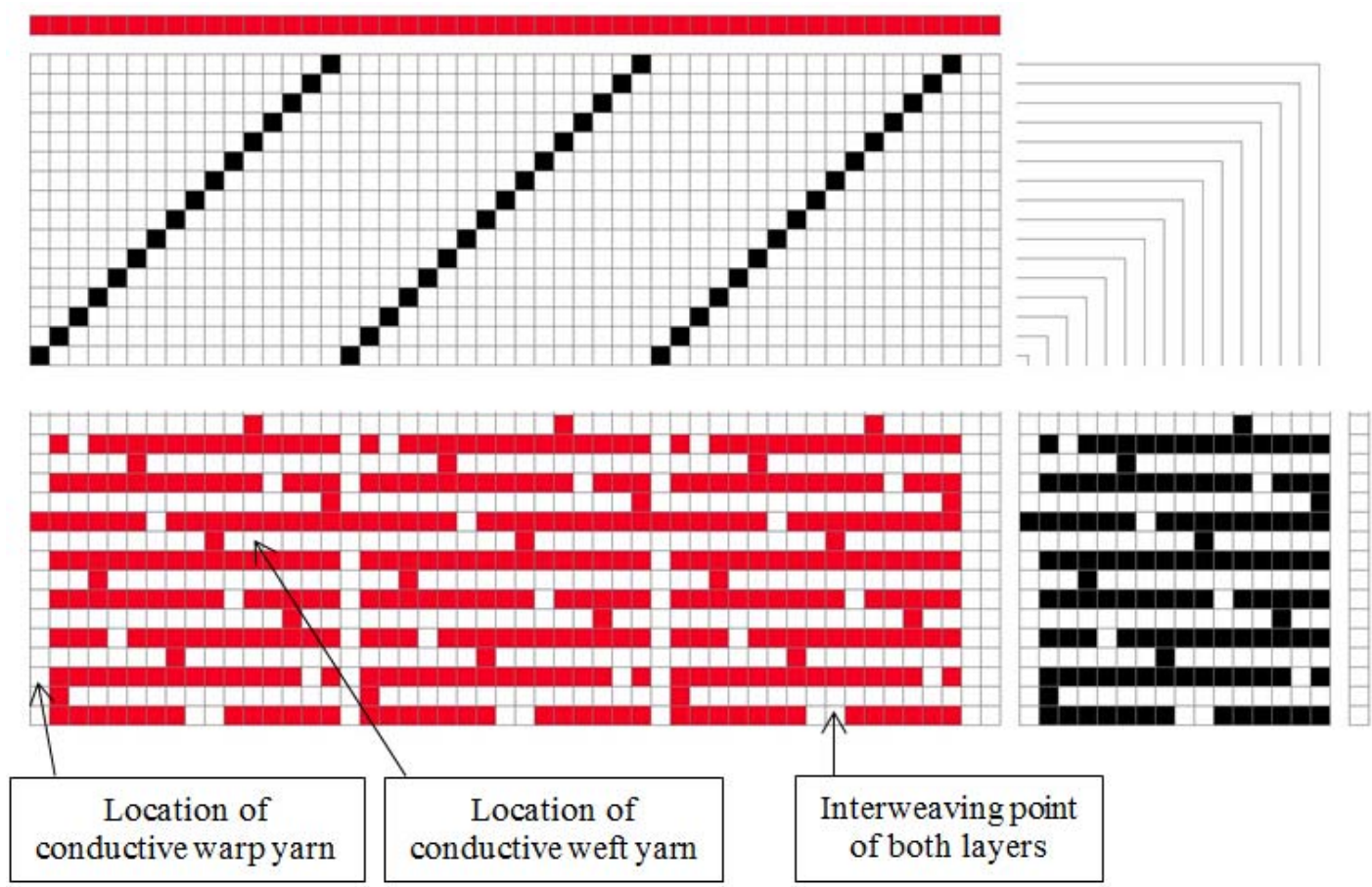

Fig.3. Weave project in Weavepoint software 


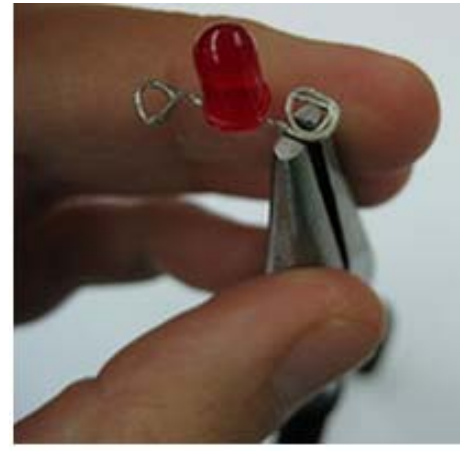

a

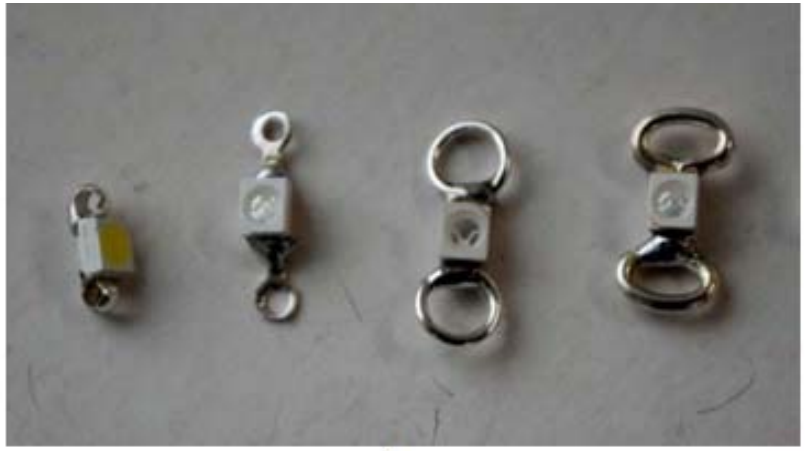

$\mathrm{b}$

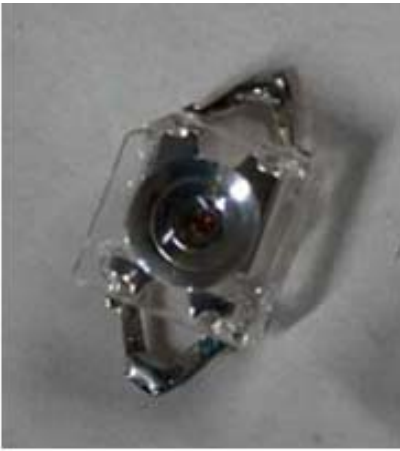

$\mathrm{c}$

Fig.4. For sewing prepared LEDs - a: T1 housing LED [7]; b: 1206 size SMD LEDs with soldered metal accessories; c: LED with soldered leads

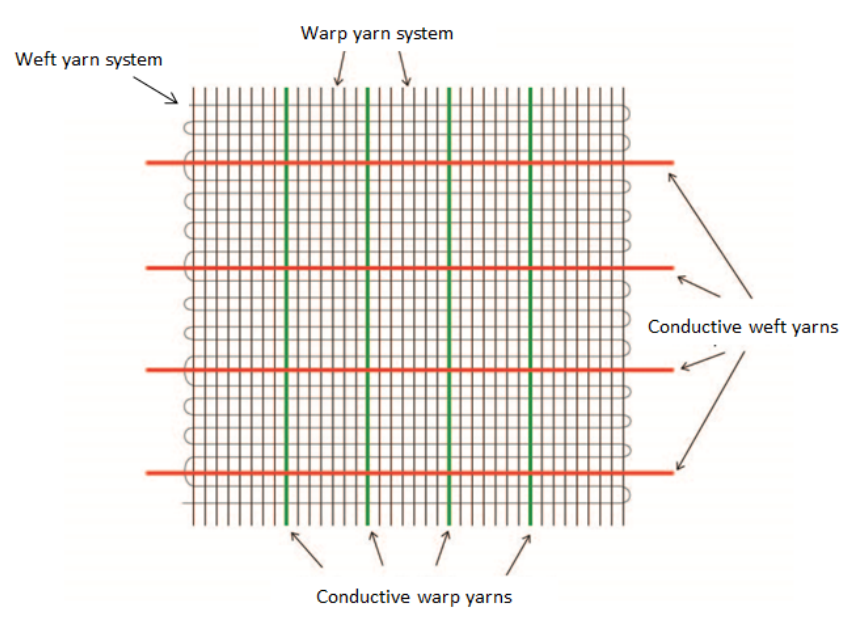

Fig.5. Placement of conductive yarns in textile

accessories small as possible to get tight enough connection between a conductive yarn and an accessory for a stable electrical contact. For the second display sample 1206 size (3 x $1.5 \times$ x1.5 mm) SMD LEDs and 1,5 mm size beads are used.
In the second version of display diodes are attached to the conductive yarn before weaving and it is woven into the textile structure together with LEDs (Fig.7.). Before weaving diodes can be attached to the conductive yarn by knotting, gluing with glue or soldering it to the yarn.

Woven textile displays with all diodes in swith-on mode are shown in Fig.8. Using matrix construction for display circuit each diode can be controlled individually, therefore it is possible to represent static or animated dynamic indication on a textile display.

\section{INTERACTIVE OPERATION OF DISPLAY}

Each diode of display operates as one pixel of image. Described display consists of 16-dot (4x4) LED matrix, but by increasing number of diodes it is possible to get an image with higher resolution. For example, the use of $35-\operatorname{dot}(5 \times 7)$ matrix display allows an approximate representation of virtually all conceivable characters [6]. If a large number of LEDs is involved in a matrix display, they are also electrically connected like

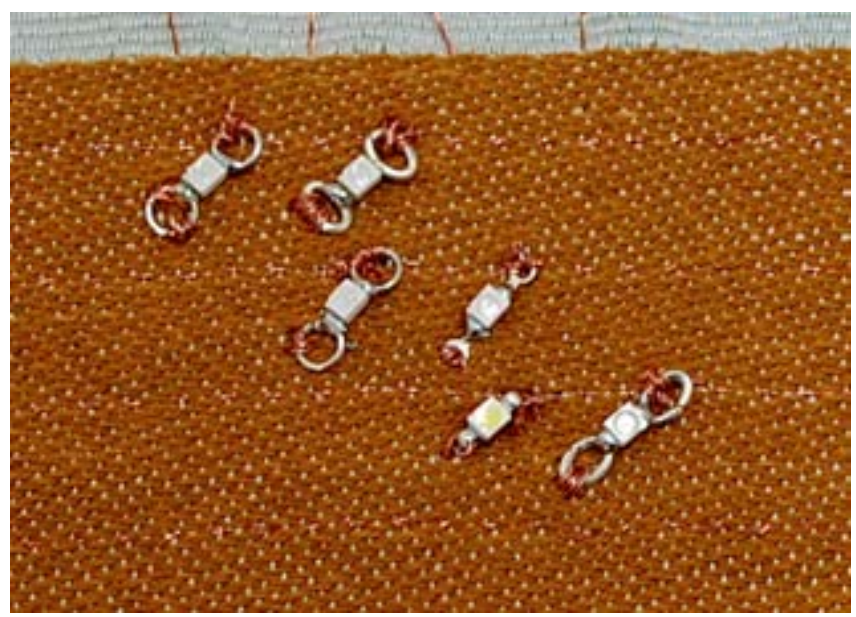

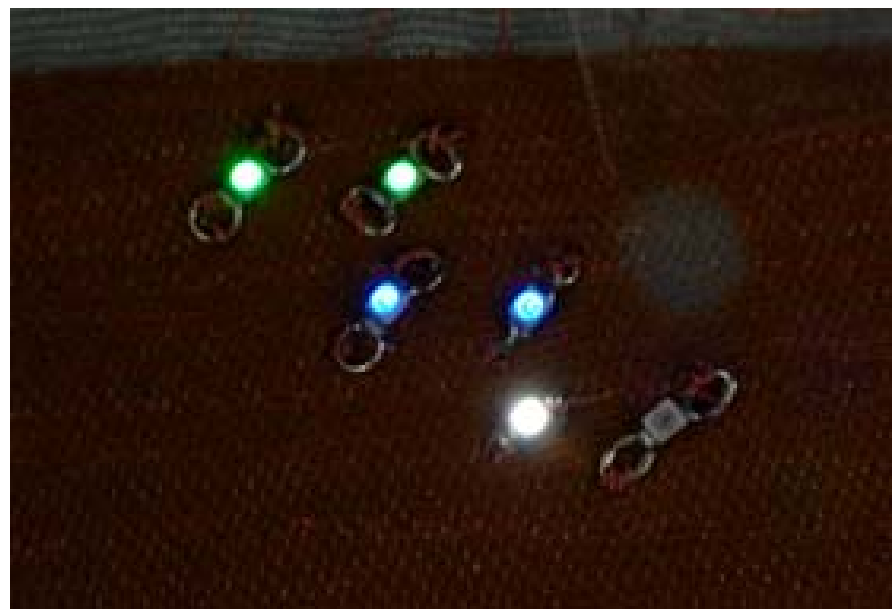

$\mathrm{b}$

Fig.6. To electrotextile attached SMD LEDs - a: switch-off LEDs; b: switch-on LEDs 
matrix - multiple LEDs are connected together in rows and columns. This can be done to minimize the number of pins required to drive them.

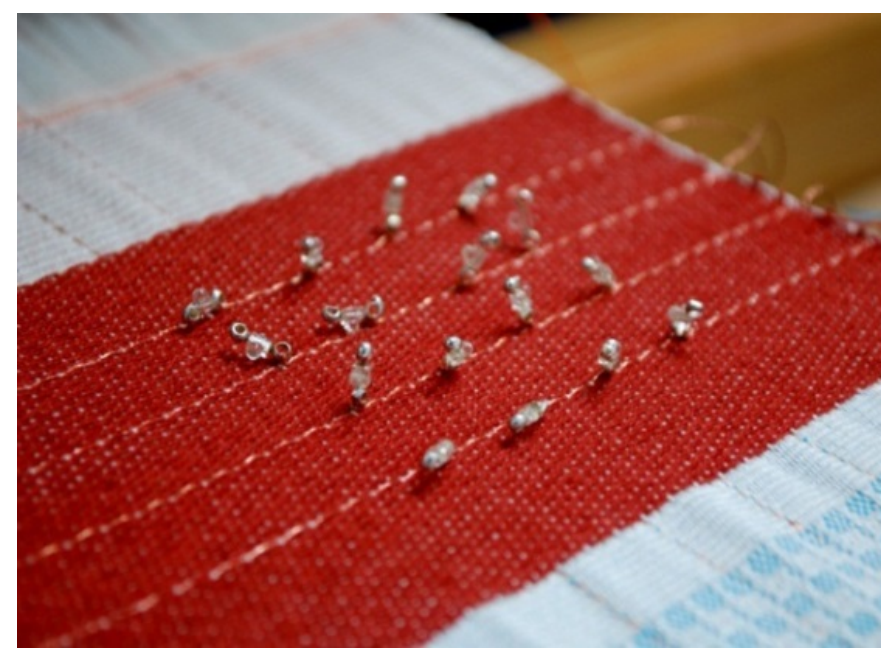

Fig.7. To electrotextile attached SMD LEDs during weaving process

\section{CONCLUSIONS}

In the paper the weaving method is described for electrotextile design. Fabric with interwoven conductive yarns was designed to which light-emitting diodes (LEDs) were attached. In such a way realized light-emitting fabric display retains conditions which are appropriate for textile and can be used for different data representation.
Using satin weave and a double-layer fabric structure, conductive weft and warp yarns are insulated from each other in intersection point of both fibers. The described approach was used to fabricate light illuminated woven fabric which can be integrated into clothing or in other object related to textile applications. This technology is not only limited to light illuminated displays but could be used to build other smart textile constructions like sensors, conductive textile traces etc.

\section{SUMMARY}

Smart textile systems different range of applications like medical (monitoring of health, medical therapeutics), safety (work wear and protective clothing), leisure and fashion etc. are widely used.

In this study the research is focused on photonic textiles, developing flexible textile-based display. Such kind of textile can be used as output interface integrated into communication clothing by representing different animated images directly on clothing.

In the research for electrotextile fabrication weaving method was used. Fully or partly replacing traditional (nonconductive) textile yarns with conductive textile yarns, it is possible to get woven conductive textile material or fabric circuit. For display textile circuit matrix construction was used, therefore it was necessary to place conductive yarns both in weft (assumed as anode) and warp (assumed as cathode) yarn systems. To avoid interconnection of both polarities in point of yarns intersection, electrotextile was designed as two layer fabric. To electrotextile light-emitting diodes (LEDs) were attached. Different types of LEDs, its preparation and attaching ways to electrotextile was described as well.

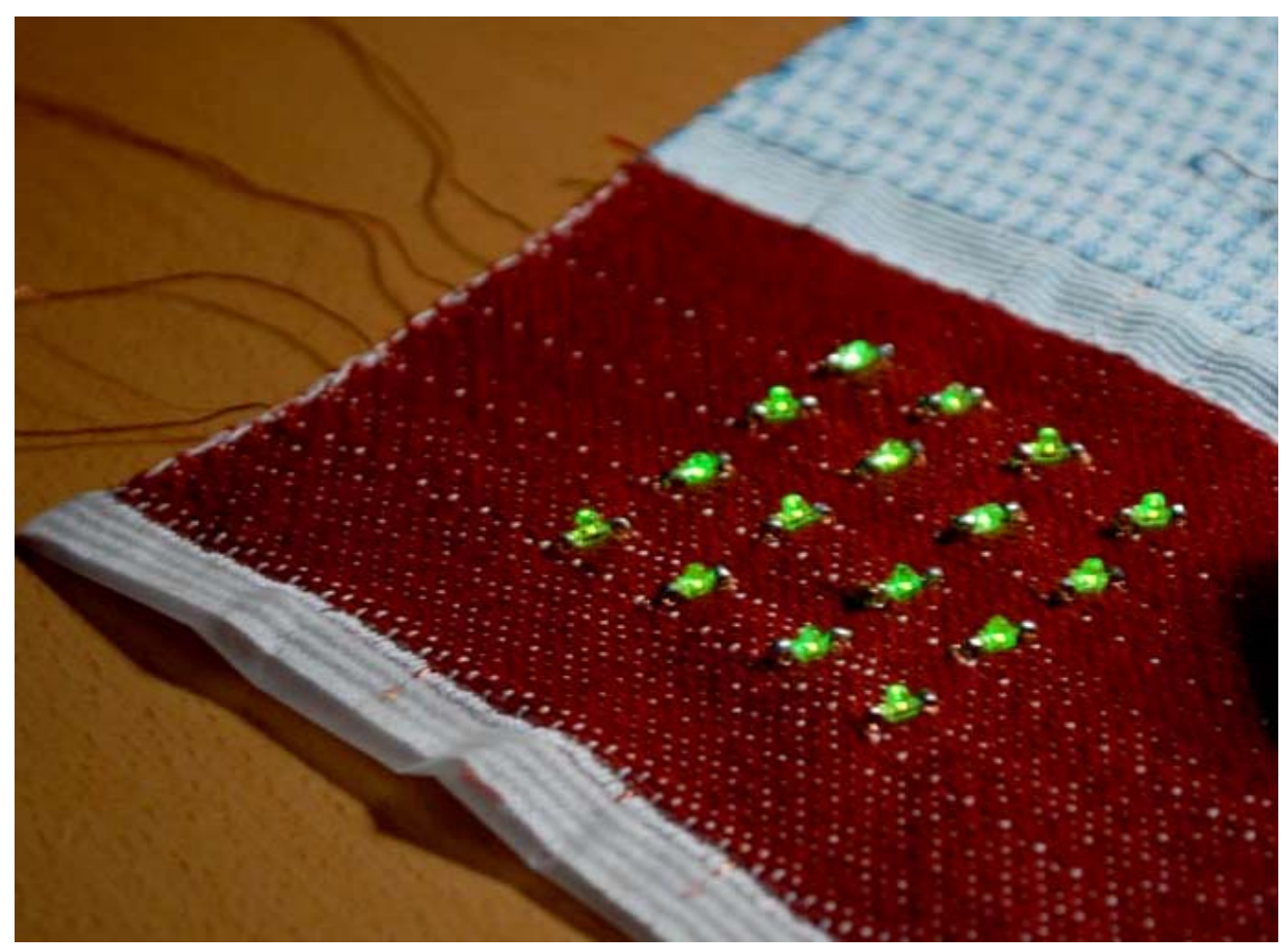

Fig.8. Woven textile display with switch-on diodes 
This technology is not only limited to light illuminated displays but could be used to build other smart textile constructions like sensors, conductive textile traces etc.

\section{ACKNOWLEDGMENT}

Author would like to thank scientific adviser prof. Ausma Viļumsone.

This work has been supported by the European Social Fund within the projects "Support for the implementation of doctoral studies at Riga Technical University".

Electrotextiles were designed in Smart Textiles Design Lab at The Swedish School of Textiles (Borås, Sweden).

\section{REFERENCES}

1. Kirstein, T., Cottet, D., Grzy, J., Tröster, G., Wearable computing systems - electronic textiles. In: Wearable Electronics and Photonics, ed. X.M.Tao. Woodhead publishing, 2005, pp 177. http://dx.doi.org/10.1533/9781845690441.177

2. Koncar, V., Communication apparel and optical fibre fabric display. In: Wearable Electronics and Photonics, ed. X.M.Tao. Woodhead publishing, 2005, pp 156.

3. Cochrane, C., Meunier, L., Kelly, F., Koncar, V. Flexible displays for smart clothing: Part I-Overview. Indian journal of fibre and textile research. Vol 36, 2011, December, pp. 422-428.
4. Ghosh, T.K., Dhawan, A., Muth J.F., Formation of electrical circuits in textile structures. In: Intelligent textiles and clothing, ed. H.Mattila. Woodhead publishing, 2006, pp 239. http://dx.doi.org/10.1533/9781845691622.3.239

5. Adanur, S. Handbook of weaving [Book]. Florida : CRC Press LLC, 2011.

6. Tietze, U., Schenk, C. Electronic circuits. In: Handbook of design and applications. 2nd ed. Springer, 2008, pp 1142-1144.

7. Actuators [online]. [viewed September 2013] Available from: http://www.kobakant.at/DIY/?p=3124. Accessed: 09.07.2013

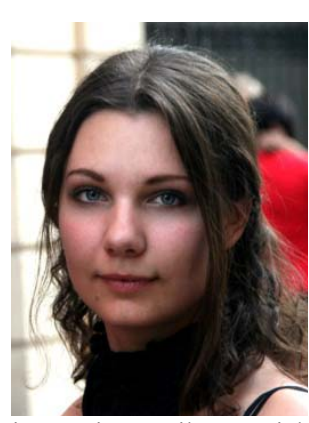

Inese Parkova. Riga Technical University, Institute of Textile Materials Technologies and Design, Mg.sc.ing, 2010. Fields of study: optical fibre fabric integration into textile products. Scientific Assistant, Institute of Textile Materials Technology and Design, RTU, Azenes 14, Riga, Latvia. GARMENT TECHNOLOGIST, LLC Solution. ASSISTANT OF PROJECT LEADER, Institute of Transport Vehicle Technologies, RTU. Werner von Siemens Excellence Award 2011; Inclusion into RTU Zelta fonds 2010 best student list; Current Doctoral research: electronic systems integration into clothing, innovative textile materials, smart clothing.

Address: Riga Technical University, Institute of Textile Materials Technologies and Design, Azenes Str. 18, Riga, LV-1048, Latvia

E-mail: inese.parkova@rtu.lv

Inese Parkova. Austs gaismu izstarojošs displejs.

Viedapgèêrbiem un viedtekstilijām ir plašs pielietojums, kā piemēram, medicīnas apgeērbs / tekstils (veselības uzraudzī̌ana, medicīniskās terapijas), drošības apgeērbs (darba apǵērbs, aizsargapéēerbs), ikdienas un modes apgeērbs utt. Šajā pētījumā ir studētas fotoniskās (gaismu izstarojošās) tekstilijas, izstrādājot elastīgu tekstila displeju. Šāda veida e-tekstilija var tikt izmantota kā izvades saskarne, piemēram, komunikācijas apǵērbā, uz kura var attēlot dažādus animētus attēlus vai tekstu. Šajā pētijumā elektrotekstila izstrādei izmantota aušanas metode. Pilnībā vai dạ̄ēji aizstājot tradicionālos tekstila pavedienus ar elektrovadošajiem pavedieniem, iespējams iegūt austu elektrovadošu tekstila materiālu jeb tekstila elektrisko shēmu. Tekstila elektriskajai ǩēdei izmantota matricas konstrukcija, līdz ar to elektrovadošos pavedienus nepieciešams izvietot audu (pieņemts kā anods) un šķēru (pieņemts kā katods) pavedienu sistēmās. Lai abas polaritātes nesaskartos krustošanās vietās, elektrotekstils tika veidots kā divkārtu audums. Pie elektrotekstila pievienotas gaismu izstarojošas diodes (LEDs). Aplūkoti arī dažādi diožu veidi, to sagatavošanas procesi un pievienošanas veidi pie elektrotekstila. Aprakstītā elektrotekstila uzbūvi var izmantot arī citiem viedtekstila pielietojumiem, piemēram, tekstila sensoriem, elektriskajiem starpsavienojumiem utt.

\section{Инесе Паркова. Тканый светоизлучающий дисплей.}

Для умной одежды и умного текстиля существует широкий спектр применений, таких как медицина (контроль за состоянием здоровья, терапия), защита (рабочая и защитная одежда), мода и так далее. В этом исследовании изучен фотонный текстиль и разработан гибкий дисплей на текстильной основе. Такой вид текстиля можно использовать в качестве выходящего интерфейса интегрированного в коммуникационную одежду, на которой можно выводить различные анимированные изображения или текст.

В этом исследовании для разработки электро-текстиля используется ткацкий процесс. Полностью или частично заменяя традиционные текстильные нити на электропроводящие нити, можно получить тканые электропроводящие материалы или текстильные электрические схемы. Так как для текстильной электрической схемы используется матричная конструкция, для этого необходимо разместить электропроводящие нити в систему утка (в качестве анода) и основы (в качестве катода).

Чтобы избежать соприкосновения обеих полярностей в точке пересечения нитей, электро-текстиль был спроектирован как двухслойная ткань. К электро-текстилю подсоединены светодиоды. Рассмотрены различные виды светодиодов, а также процессы подготовки и методы подсоединения их к электротекстилю.

Описанная технология также может быть использована для создания других конструкций умной ткани, например текстильный сенсор, текстильные электрические соединения и т.д. 